Aldebarian and Antarian types to helium stars. This, he states, conforms to the thermal classification which Sir Norman Lockyer deduced from his qualitative study of the stellar spectra.

The IVORK of SiR IVilliam Huggins.-Under this heading, in The Astrophyical Journal for April (vol. xxxvii., No. 3) Prof. G. E. Hale takes the opportunity of again cheering up those astronomical observers who possess only a small and limited instrumental equipment, and may conceive the idea that the multiplication of large instruments renders any attempt at research on their part useless. Being the director of an observatory which may be considered the best equipped, contains the largest instruments, and is situated on a nearly ideal mountain site, it may appear that he is only trying to console workers with modest means. But this is not so. Prof. Hale knows the value of both large and small instruments, and there is abundant work for both classes. The reader should look through this article and he will find depicted there the magnificent work of amateurs, in spite of the fact that large instruments were in active employment at the time the work was done. Sir William Huggins he takes as an example of one of "that great English group of amateurs," and he directs attention to the fact that while in 1856 he acquired his first telescope, a 5 -in. refractor, in 1858 an 8 -in., and in 1870 an 18-in. reflector, such powerful instruments as ${ }^{5}$-in. refractors at Pulkowa and Harvard, Lord Rosse's 6-ft. reflector, Lassell's 4-ft. reflector, the Melbourne 4 -ft. reflector, \&c., did not deter him from securing results of the highest importance.

Prof. Hale concludes in the following terms :"Every investigator may find useful and inspiring suggestions in the life and example of Sir William Huggins. Their surest message and strongest appeal will be to the amateur with limited instrumental means, and to the man, however situated, who would breals new ground."

\section{THE SCOTT EXPEDITION TO THE} ANTARCTIC.

$T H E$ huge audience which filled the Albert Hall on Wednesday evening, May $2 \mathrm{I}$, on the occasion of the Royal Geographical Society's meeting to hear Commander Evans's account of the Scott expedition to the Antarctic, showed no less by its eager plaudits than by its suppression of them at the fitting moments that the public sense of the tragedy of the expedition is not dulled by familiarity. Yet throughout the proceedings there was no false note of sentiment; the president, Lord Curzon, stated, without risk of misunderstanding, that the tribute of the society to the dead had been paid already, and begged any (and there were some) who felt that "this great reception is inconsistent with the feelings of sorrow which affect us all " to "abandon such a reflection," for that he was sure that Scott himself would not have had his companions forgo the reward of their labour. And the story of the expedition was told by Commander Evans very simply; he exhibited the sense of loss which all his collaborators share in a few words only, and by implication rather than by direct statement. Finally, the tribute paid by both president and lecturer to the generosity of the public and to the Government for the provisions made for the dependants of those who are lost showed that any criticism which has been directed against the allowances made from the public funds is without official concurrence.

It was satisfactory to learn that the funds subscribed will admit of the proper publication of the scientific results of the expedition. As regards these results, not a great deal emerged from the lecture which was not already realised by those who have taken interest in this aspect of the work accomplished. Nor was it to be expected that any detail should be given within the compass of a single lecture, though long; for it was long, and a tribute is due to Commander Evans, who so ably sutained the strain of delivering it, and never for a moment allowed the intense interest of the audience to wane. And here a word, though perhaps scarcely appropriate in this place, may be permitted in commendation of the singularly well-chosen organ music which was given before the opening of the proceedings.

But if it is scarcely possible, after hearing the lecture, to add materially to what is already known as to the scientific results of the expedition, it is right at the outset to record the full measure in which the value of those results has clearly been enhanced by photography. Obviously no photographer to any expedition has laboured with a more thorough sense of his duty, or more successfully, than Mr. Ponting. The lecture was delivered with lowered lights and with an accompaniment of lantern slides throughout, and was followed by a few kinematograph films of extraordinary interest. It is impossible to over-praise the beauty of the photographs, nor is it easy to select those of chief scientific interest, though an exquisite series showing new ice at successive stages of formation may be specially mentioned. Of the moving pictures, those of the killer whales were singularly clear, though the motion of creatures of their kind is familiar to many; those which showed seals leaving and entering the water through ice-holes were of even greater interest and value.

Some wonder has been expressed, with the vast area unexplored in the Antarctic region and the many problems awaiting solution in mind, that Scott elected to follow Shackleton's route, or even (and this criticism dates from early Arctic days) that he or anyone else should desire to reach the geographical pole at all. Against this there should be recalled the desire once expressed by a high Antarctic authority, that the south pole should be reached as quickly as possible since, until it should be, explorers would not rest content with work in other directions merely. On this count criticism is scarcely to be directed against Scott ${ }^{\text {s }}$ expedition, for it included the largest scientific staff ever taken to the Antarctic, and scientific research certainly played no subordinate part in relation to the journey to the pole. We know already of the devotion with which Scott himself and his lost companions carried their geological specimens to the end of those last dreadful marches. Commander Evans showed how the three weeks during which the ship was held in the pack on the outward voyage were "not wasted," for magnetic observations, soundings, and serial sea temperatures were obtained, while marine biological work of importance was also done. Only the impossibility of finding a suitable base at Cape Crozier prevented the expedition from landing there in order that the embryology of the emperor penguins during winter might be studied. Wilson afterwards made his famous winter expedition thither, and one heard how he recorded the unimagrinable temperature of $109^{\circ}$ of frost.

Mr. Griffith-Taylor's party, which traversed the Ferrar Glacier, broke new ground, reaching a valley free of snow, containing a fresh-water lake only surface-frozen and full of algæ. Gravels in this limestone region, rich in garnets, "were washed for gold, but only magnetite was found." Commander Evans also paid tribute to Dr. Simpson's work as physicist and meteorologist, which was carried on after his departure by Mr. Wright, who also "made a special 
study of ice structure and glaciation." Lieut. Campbell's party, in spite of extraordinary hardships, which included wintering away from its base, for which it was not prepared, was very successful in meteorological, magnetic, geological, and surveying work, while the penguins were the object of further study. Commander Evans had time to commend the worls of Mr. Griffith-Taylor on the coast of Victoria Land (in geology and survering), as well as that carried out on the ship, not only in the open ocean, but on the lessknown coasts of New Zealand, no more fully than to intimate that each of these departments of the whole great undertalsing is worthy of a lecture to itself, which it is to be hoped may be devoted to it.

Finally, reference is due to the results of the determination of the position of the south pole itself, as obtained by Amundsen and by Scott. The latter fixed the exact spot by means of a 4 -in. theodolite, "at a point which only differed from Amundsen's reckoning by half a mile," that is to say, "by one scale division on the theodolite, which was graduated to half a minute of arc. Experts in navigation and surveying will always look on this splendidly accurate determination as a fine piece of work, by our own people as well as by the Norwegian explorers."

At the annual meeting of the society on Monday last, in the 'Theatre, Burlington Gardens, Lady Scott was presented by Earl Curzon with the patron's medal and the special Antarctic medal awarded to her husband in rgo4, inclosed in an inscribed silver casket. Mrs. IVilson also received a patron's medal awarded to Dr. E. A. IVilson. To Lieut. Campbell was presented a gold watch as a special award.

\section{THE BRITISH SCIENCE GUILD.}

THE seventh annual meeting of the British Science Guild was held at the Mansion House on May $2 \mathrm{I}$, the Lord Mayor in the chair. In his opening remarlis, the Lord Mayor made sympathetic reference to the aims and work of the guild, which, he said, seeks to further the application of scientific methods to all human endeavour and advocates the adoption of measures for the conservation of natural resources; in other words, its desire is to foster national efficiency. The Right Hon. Sir William Mather was elected president of the guild in succession to Lord Haldane, who has been president since its foundation. The new vice-presidents elected were Lord Sydenham, the Right Hon. the Lord Mayor of London, the Right Hon. Sir John Brunner, Bart., Sir Patrick Manson, and Sir Philip Watts; and other new members added to the executive committee are Mr. Charles Bathurst, M.P., Mr. R. Kaye Gray, Sir Philip Magnus, M.P., and Mr. Robert Mond.

The annual report, which was adopted at the meeting, surveys the activities of the guild in many directions. Reference is made in it to the new Post Office service for the synchronising of clocks-a subject which the guild has done much to promote. Other matters referred to are the final report of the Royal Commission on Tuberculosis, the new horticultural branch of the Board of Agriculture and Fisheries, the conversion of the Sleeping Sickness Bureau into the Tropical Diseases Bureau, the Society for the Promotion of Nature Reserves, and the Royal Commissions and Departmental Committees appointed during the year to deal with subjects with which science has some relationship. All these Commissions and Committees have been announced already in NATURE, but the report of the guild brings them together in a convenient form as a record of official action.

The various committees of the guild continue to do NO. 2274 , VOL. 9I] valuable work. The medical and agricultural committees have drawn up a report on the Government's Milk and Dairies Bill. While recognising that the Bill is a very decided advance in the direction of obtaining pure milk, the committees feel that in certain respects stronger and more drastic action should be taken. A note upon the report of the committees appeared in NATuRE of May I (p. 222).

A report on tide and wave energy, and on the possibility of utilising this form of energy for power purposes, is being drawn up by the committee on the conservation of natural sources of energy; also a report on the utilisation of peat, which occurs in such enormous quantities in some districts in the British Isles and British possessions.

Owing to the declaration of the Government of the intention to bring in a comprehensive scheme to reorganise the educational system of the country, a joint committee of the education committee and the technical education committee, with Sir William Mather as chairman, was appointed to consider the subject. A valuable report has been drafted, which urges that a scientific system of national education demands:-

(I) The duty of local authorities to make such previsions as will promote healthy growth during infancy and throughout school life.

(2) The absolute necessity of manual work and related practical exercises throughout the whole course of school instruction, and also in the training of teachers.

(3) Efficient public elementary schools within the reach of all children, and attendance at school compulsory until the age of fourteen years is reached.

(4) Attendance at continuation schools for at least six hours per week obligatory up to seventeen years of age for all young persons not otherwise receiving suitable education.

(5) Suitable secondary schools available for all who can profit by them and will undertake to complete the full course of instruction.

(6) The institution of school certificates to serve as passports to higher schools or universities, or as testamurs of satisfactory completion of a school course.

(7) Examinations to occupy a secondary place in comparison with school records for the award of certificates, or to qualify for promotion to higher courses of study.

(8) Coordination of technical institutions and faculties of technology in universities in order to prevent overlapping and render specialised types of technological training available to students who have the canacity to profit by them.

(a) Increased grants to universities and other places of higher education for the purposes of ensuring the reduction of fees for all courses and promoting postgraduate research.

(Io) The position and condition of service of teachers of every grade to be greatly improved in order to encourage men and women of the highest aptitude and qualifications to devote their lives to the work of teaching and the advancement of knowledge.

(xi) Readjustment of the shares of the cost of education borne by the National Exchequer and by local authorities, so that educational progress may be made primarily a national responsibility.

The synchronisation of clocks committee refers to the Government action in connection with the subject, already mentioned. Since the guild took the matter up the Post Office has always viewed the matter sympathetically, and this new departure will, if it be taken up by those exposing public clocks, be 